\section{Budget Cuts and Administrative Bloat}

\section{Lionel S. Lewis}

Lionel S. Lewis is professor of sociology and adjunct professor of higher education at SUNY/Buffalo. Address: Park Hall, SUNY/Buffalo, Buffalo, NY 14260, USA.

$\mathrm{T}$ he financial constraints on U.S. colleges and universities in recent years have forced students to cope with fewer options and larger classes. One limited survey in 1992 reported that more colleges and universities than in an earlier study were simultaneously increasing the size of classes, reducing the number of full-time faculty, and increasing teaching loads. Class sizes were growing most rapidly in introductory and lower-division courses.

In addition to economies in the classroom, academic administrators have tried other ways to deal with the dollar gap. Some have deferred maintenance. Others have raised tuition and fees. A number of institutions report that they have been tightening budgets for some non-student-funded undergraduate activities. Nevertheless, while making savings in some areas, administrators have as a class greatly proliferated, putting a new strain on institutional budgets.

One set of statistics shows that between 1975 and 1990, college and university enrollments rose 10 percent, the number of full-time faculty members increased 21 percent, and administrative positions grew 42 percent. On most campuses senior administrators are served by a growing number of minions called "associate," "vice," "deputy," "assistant," and "assistants to" in dealing with academic, research, administrative, graduate, student, athletic, public relations, development, business, and alumni matters.

To be sure, there is a greater need for administrative involvement in record keeping, financial aid, fundraising, compliance with state and federal government regulations, and expanding student and faculty services. Faculty show little interest in taking on any of these tasks. Indeed, they constantly complain of being overburdened with administrative responsibilities as it is. As a consequence of the growing demand for more middle-level administrative personnel, fewer than one-third of those presently employed in higher education are directly engaged in educating - two-thirds are administering or assisting those administering.

According to the U.S. Equal Employment Opportunity Commission, there was a rapid and significant growth in nonteaching employees in institutions of higher learning between 1975 and 1985. It is worth noting, however, that over the same period enrollment grew by 9.5 percent, so that in 1985 there were fewer full-time faculty per student in American institutions of higher learning than in 1975. The steady drift toward fewer full-time faculty per student has continued into the 1990s in both public and private institutions.
The trend in administrative bloat has been uninterrupted. There are, for example, more specialists involved in public relations and marketing. One study shows that between 1985 and 1990, other professionals grew by 28 percent, executives by 14 percent, and faculty by less than 9 percent. Between 1985 and 1990, institutions of higher learning hired about twice as many nonteaching staff members as faculty members. In the 1980s, at some large research universities such as the University of Pennsylvania and Ohio State University, nonteaching professionals increased by over 100 percent. One cannot help but note the irony in the fact that at a time when colleges and universities were most loudly marketing themselves as institutions particularly committed to teaching, the proportion of employees who actually taught was steadily decreasing. The question that needs to be asked, of course, is: how much administrative growth was truly necessary during this period?

\section{There was a rapid and significant growth in nonteaching employees in institutions of higher learning between 1975 and 1985.}

The point here is not simply the number of people, but, more importantly, costs. Since the 1920s, the proportion of college and university expenditures for administration have doubled. In every decade from 1930 to 1980 the growth in spending for administration outpaced the growth in spending for teaching. In the 1980s, administrative budgets grew 26 percent faster than instructional budgets.

In the 1930s, institutions of higher learning spent 19 cents on administration for every dollar spent on instruction. By 1950, the figure was 27 cents. In the 1987-88 academic year, it was 45 cents. In the same year, the cost of administration (not including libraries, student services such as counseling, admissions or placement, expenditures for the physical plant, or outlays for research) was $\$ 1,742$ per full-time student. (In contrast, in 1980 the cost of administration was only $\$ 1,189$ in 1988 dollars - per full-time student.)

According to figures from the American Council on Education, between 1975 and 1985 faculty salaries in public institutions grew by a little more than 82 percent, while those of administrators (from presidents to financial aid directors) grew by about 89 percent. In private institutions, the salary increases of administrators were only slightly greater than those of faculty.

A national survey of every private research university and highly ranked doctoral university, master's university and college, and liberal arts college (a total of over 400) found that, in 1992-93, 8 chief executives earned more 
than $\$ 400,000$; 10 more received at least $\$ 300,000$ in salary, fees, bonuses, and benefits; 67 were paid between $\$ 200,000$ and $\$ 300,000$; and the total salary and benefits for 62 others was between $\$ 175,000$ and $\$ 200,000$.

Across the country, administrative salaries have for years been higher than faculty salaries, and it is taken for granted that this is as it should be. In the last two decades the inequality has grown significantly. The consequence of this conjuncture is, among other things, an even steeper decline in the proportion of academic budgets available for rewarding efforts in teaching.

There are two obvious explanations for the striking growth of administrative salaries. First, some would contend that administrative salaries are market driven-that the skills necessary for staff work in colleges and universities, leadership ability for example, are truly out of the ordinary. There is a seller's market for academic administrators and their uncommon talents. They are in great demand. Any number of institutions of higher learning are eagerly waiting to recruit them. This external labor market for academic administrators drives up their salaries.

Although this interpretation may sound reasonable, it is not supported by fact. Indeed, research shows that the labor market forces that affect the salaries of academic administrators are relatively weak. There is not much of an external labor market competing for academic administrators. The majority spend their entire career in one or two institutions. It is rare for them to find positions at an institution with more prestige than the one at which they are located. About half move into their positions from within the same institution.

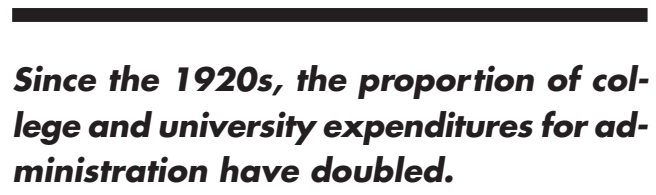

In light of the disproportionate share of economic resources taken by them, it would not be unfair to fault academic administrators, at least in some part, for the situation in American colleges and universities with regard to teaching. The claim is heard that they are sympathetic about the putative imbalance in the reward structure in higher education. However, not only have they done little to address it, but their excessive claims on limited resources have clearly exacerbated the situation. It thus seems self-evident that the more spent on administration, the less that can be spent on things other than administration.

This article is an abbreviated version of chapter 10, Marginal Worth: Teaching and the Academic Labor Market (New Brunswick, NJ: Transaction Publishers, 1996).

\section{A Coming Student Revolution?}

\author{
Philip G. Altbach \\ Philip G. Altbach is Monan professor of higher education and director \\ of the Center for International Higher Education at Boston College.
}

$\mathrm{I}_{\mathrm{t}}^{\mathrm{t}}$ is time to consider the impact on students of the various academic crises affecting higher education worldwide. The student political activism of the 1960s is but a dim memory now, but the fact is that students can and do still react, sometimes violently, to campus change and deteriorating conditions. There are indications that students may again take to activism, adding an important dimension to the academic equation. It is surprising that students have been so quiet worldwide as campus conditions deteriorate. There are signs that students are again becoming a force to be reckoned with.

The most dramatic example of student reaction now is in Germany, where the largest student demonstrations since the 1960s have taken place in the past few months to protest the rapidly deteriorating conditions in German universities. Massive demonstrations in Berlin, Frankfurt, and other cities have involved thousands of students in protests against budget cuts, overcrowding in the universities, and the general neglect of the universities by German authorities, who have been focused on economic problems and the challenges of reunification. It is widely recognized that the universities have suffered dramatically in recent years. They have been forced to absorb major increases in student numbers without added resources. This has led to overcrowding. Students now take seven or more years to finish their first degrees. Some are even choosing to study in other countries, such as the Netherlands, where academic conditions are better.

After suffering silently for almost a decade, the current wave of demonstrations has forced governmental authorities to take notice. So far, the only reaction has been finger-pointing by federal and state authorities.

In France, students over the past decade have taken to the streets to protest against educational reforms aimed at rationalizing the French university system and making student funding income related. Students succeeded in halting the reform, and French politicians, regardless of party, are reluctant to propose any new changes in current policy for fear of arousing student opposition.

It is somewhat surprising that students in other European countries have not taken to the streets. Throughout Europe, universities have experienced a combination of increased enrollments and stagnant or decreased funding. Italy has been especially hard-pressed, and the conditions of teaching and learning in Italian universities are among the worst in Western Europe. British higher education has been profoundly restructured in recent years. Margaret Thatcher's Conservatives totally reorganized the system, creating new universities by upgrading the polytechnics to university sta- 